\title{
Ecological Studies on Some Land Gastropod Species at Zagazig District, Sharkia
} Governorate

Ismail, Sh. A. ; M. F. I. Ghaly $^{2}$; A. E. El-Sayd ${ }^{2}$; Samah, M. Abdel-Kader ${ }^{1}$ and Asmaa M. A. El-Sayd ${ }^{1}$

${ }^{1}$ Plant Protection Research Institute, Agric. Res. Center Dokki, Giza, Egypt

${ }^{2}$ Faculty of Science, Zagazig University, Zagazig, Egypt

\section{ABSTRACT}

Survey, population structure of some land snails' species in five different localities at Zagazig district, Sharkia Governorate were studied. A field survey was carried out at Sharkia Governorate in Sheeba, Banayous, El-Aslogy, Kafr El-Hosor and Kafer El-Zagazig villages during the period from November 2013 to May 2014. Results revealed that only two species of terrestrial snail were found, Monacha cartusiana that showed a very wide distribution range in all surveyed villages than Succinia putris which appeared only in Kafer El-Zagazig. Highly dense population of snails were found on the Egyptian clover, followed by lettuce, cabbage while wheat, maize and rice showed less numbers. The initial infestation of the Egyptian clover with $M$. cartusiana was appeared in September with low numbers (1.33 and 4.33 snails) per quadrate sample, reaching its maximum in April with values of 64.80 and75.80 per quadrate sample during the growing season of 2013/2014 and 2014/2015, respectively. Population dynamics of adults and juveniles $M$. cartusiana fluctuated during the different seasons, whereas population density remained at partially low numbers during winter months, gradually increased during spring till reached a peak of 40.40 and 45.80 snails $/ 0.25 \mathrm{~m}^{2}$ by the beginning of April for juveniles and of 37.80 and 43.20 snails $/ 0.25 \mathrm{~m}^{2}$ for adults in mid-April during 2013/2014 and 2014/2015, respectively. It declined thereafter during Sept. and Oct.(0.0,1.3 and 0.0, 4.3)and $\left(0.0,6.67 \mathrm{and} 0.0,11.33\right.$ snails $\left./ 0.25 \mathrm{~m}^{2}\right)$, for juvenile and adult snails during 2013/2014 and 2014/2015 respectively. In addition, there is no definite correlation between temperature or relative humidity and population density of $M$. cartusiana during the two successive growing seasons.

\section{INTRODUCTION}

The terrestrial mollusks are considered as major pests of a wide range of agricultural and horticultural crops in temperate and humid habitats worldwide (Speiser and Kistler 2002). Land snails amongst class of Gastropoda (subclass: Pulmonata) are one of the most numerous with almost 35,000 described species of the world (Solem, 1984). It has now invaded the most Governorate of Egypt (Mahrous et al. 2002 and Heikal, 2015) as a result of the agriculture and horticulture activities, (Barker, 2002).The spreading of land snails following its establishment has been related to its dispersal capability and the great capacity of adaptation in the ambient conditions (Acuna and Brandolini 2007).The land snails causing serious damages to a wide variety of plants including horticulture, field crops, and forestry as consequence of feeding activities on leaves, roots, tubers and ornamental plants as well as, citrus, peach, plam and vegetable, i.e. cabbage, carrot and bean. (Ismail et al. 2003 and Shahawy et al. 2008), destroying plant seedlings( Ghamry et al. 1993) and this has resulted in a serious decline in its quality and their yields or indirect damage by left unpleasant slimy tracks on the injured parts making humans and farm animals refuse eating on these plants( Sallam et al. 2009). Several species of land snails are recorded on various hosts of agriculture crops in different sites of Sharkia governorate (Arafa,2006 and Abou Senna et al. 2016).

On the other hand, the awareness is growing that successful control of land snails requires a detailed knowledge of the dynamics of its dispersion. The present study aims to study some ecological aspects including survey, population structure (fluctuation and dynamics) for the most common species infesting certain field crops across the study region at Zagazig district ( Sheeba, Banayous, El-Aslogy, Kafr El-Hosor and Kafer El-Zagazig villages, Sharkia Governorate .

\section{MATERIALS AND METHODS}

1. Survey of land snails on different crops at Zagazig district (Sharkia Governorate):

The field experiments were carried out in five villages( Sheeba, Banayous, El-Aslogy, Kafr El-Hosor and Kafer El-Zagazig) belonging to Zagazig district, Sharkia Governorate during the period from November 2013 to May 2014. The survey was undertaken on many host plant species including field crops as Egyptian clover (Trifolium alexandrinum), wheat (Triticum vulgaris), maize (Zea mays) and rice (Oryza sativa); and vegetable crops as cabbage (Brassica oleracea), lettuce (Lactuca sativa). At each locality of the investigated areas, a fixed area $50 \times 50 \mathrm{~cm}$ (Staikou and Lazaridou- Dimitriadou, 1990) at the border of each site was examined. All the collected snails' specimens from each host plant at different study regions of the examined areas were recorded and used to estimate occurrence and identified according to the systemic keys given by Godan (1983) .

\section{Population dynamics of M.cartusiana on Egyptian} clover .

The population dynamics of $M$. cartusiana snails was studied on a field cultivated with Egyptian clover at Sheeba locality, Zagazig district, Sharkia Governorate during two successive growing seasons (2013/ 2014 and 2014/2015). An area of about one feddan was defined as experimental site. Five replicates of quadrate sample size $(50 \times 50 \mathrm{~cm})$ were randomly examined after the dawn at biweekly intervals during the growing season of each crop (Staikou et al. 1988). All alive snails found on both plants and soil surface were counted and left in their initial places (Baker and Vogelzeng, 1988). Data concerning temperature and relative humidity were obtained from the Metrological Station of Zagazig throughout the period of study. The obtained data were subjected to statistical analysis using $\mathrm{F}$ test and correlation coefficient between snail population and each of temperature and relative humidity was performed according to Costat Statically computer program (2005). 
3. Seasonal population fluctuation of juveniles and adults of M. cartusiana.

The monthly fluctuation in numbers of the predominant glassy clover snail of $M$. cartusiana were determined on the heavily infested field which cultivated with Egyptian clover at Sheeba locality, Zagazig district during 2013/ 2014 and 2014/ 2015.As the same method which was mentioned before all alive juvenile along with adult snail individuals found on both plants and above soil surface in the quadrate sample were counted and used to estimate the population fluctuation.

\section{RESULTS AND DISCUSSION}

\section{Survey of land snails on different crops at Zagazig district ( Sharkia Governorate):}

An extensive field investigation was carried out on land snails infesting different crops at five villages belonging to Zagazig district at Sharkia Governorate during the period from November 2013 to May 2014. Data presented in Table (1) indicated that two species of land snails belonging to order: Stylommatophora were found on different host plants at at Zagazig district . These species were; the glassy clover snail, $M$. cartusiana and the amber snail, S. putris. The dispersal and infestation level of identified species were influenced by variation in habitat and host plant. It can be noted that $M$. cartusiana has the superior on snail incidence compared to $S$. putris, since it was recorded in all surveyed localities. Moreover, the majority of the examined plants were infested by this snail. Generally, the host plant infestations could be arranged: into three categories according to the level of infestation with $M$. cartusiana. These categories were; heavy, moderate and light infestation. The heavy infestation crop was found on the Egyptian clover followed by lettuce, cabbage (moderate infestation). However, wheat, rice and maize were detected with light infestation in Zagazig locality. It was clear that, $M$. cartusiana was the most frequent species existing in the five villages compared with $S$. putris which rarely in its presence and only appear in one locality.

Table 1. Survey and infestation levels of M. cartusiana at Zagazig district during the period from November 2013 to May 2014.

\begin{tabular}{lcl}
\hline Villages & \multicolumn{1}{c}{ Snail sp. } & \multicolumn{1}{c}{ Host plants and levels of infestation } \\
\hline Sheeba & M. cartusiana & Clover $(+++)$ Cabbage $(++)$ Maize $(+)$ Wheat $(+)$ Rice $(+)$ Lettuce $(++)$ \\
Banayous & M. cartusiana & Cabbage $(++)$ Maize $(+)(+++)$ Clover Wheat $(+)$ Rice $(+)$ lettuce $(++)$ \\
El-Aslogy & M. cartusiana & Clover $(+++)$ Cabbage $(++)$ Wheat $(+)$ lettuce $(++)$ \\
KafrEl-Hosor & M. cartusiana & Clover $(+++)$ Cabbage $(++)$ Lettuce $(++)$ Wheat $(+)$ \\
KaferEl-Zagazig & M. cartusiana S. putris Clover $(+++)$ Cabbage $(++)$ Wheat $(+)$ Clover $(+++)$ \\
\hline
\end{tabular}

$(+)=$ Light infestation (less than 15 snails $50 \times 50 \mathrm{~cm})$

$(++)=$ Moderate infestation $(15-30$ snails $50 \times 50 \mathrm{~cm})$

$(+++)=$ heavy infestation (more than 30 snails $50 \times 50 \mathrm{~cm}$ )

2-Population dynamics of $M$. cartusiana on Egyptian clover at Zagazig district .

The seasonal variation in population dynamics of M. cartusiana snail in relation to temperature and relative humidity was studied on the Egyptian clover field during the two growing seasons 2013/2014 and $2014 / 2015$ at Sheeba village, Zagazig district, Sharkia Governorate.

Data in Table (2) revealed that, the initial infestation of $M$. cartusiana begain to appeared with slightly low number of snails (1.33 and 4.33 snails $/ 0.25 \mathrm{~m}^{2}$ ) in the beginning of September, then gradually increased till reaching the maximum numbers to be 64.80 and 75.80 (snails $/ 0.25 \mathrm{~m}^{2}$ ) in the beginning or mid- April during the growing season of 2013/2014 and $2014 / 2015$, respectively, then a marked decreased in the population density of $M$. cartusiana by the end of the growing season of the Egyptian crop.

Generally, it was clearly that the highest population density of $M$. cartusiana was recorded during spring months (March and April)in compared with winter and autumn months and there was a steadily increasing in population density as indicated by the general mean value of population density which much higher(39.07), in2014/2015 than (30.94) in 2013/2014.

On the other hand, the correlation between some climatic factors (temperature and relative humidity) and population density of $M$. cartusiana during the two successive growing seasons was subjected to statistical analysis. Data presented in Table (2) revealed that temperature and relative humidity showed a variable effect on population density of $M$. cartusiana. Temperature and humidity showed significant effects on numbers of $M$. cartusiana during the 2013/2014 season while was insignificant effects during the 2014/2015 season.

3- Seasonal population fluctuation of juvenile and adult $M$. cartusiana on Egyptian clover at Sheeba village, Zagazig district, Sharkia Governorate.

The survey study showed that the glassy clover snail M.cartusiana was the predominant species with a relatively high numbers on major economic crops. Therefore, seasonal population fluctuation of juvenile and adult of $M$. cartusiana snails was studied on Egyptian clover field during the two growing seasons 2013/2014 and 2014/2015 at Sheeba village, Zagazig district, Sharkia Governorate.

Data in Table (3) revealed that, adult of $M$. cartusiana snails were found in Egyptian clover field throughout the year months. The lowest monthly number were determined at September or October months. Numbers of counted adult snails per sample were $1.33\left(4.67,6.67 / 0.25 \mathrm{~m}^{2}\right)$ and $4.33(7.33$, $11.33 / 0.25 \mathrm{~m}^{2}$ ) during Sep. and Oct. of 2013/2014 and 2014/2015, respectively. While juvenile of $M$. 
cartusiana snails were found throughout November to May months. The lowest values of population density were determined during November or December months. Numbers of counted juvenile snails per sample were $1.67,2.00$ and $7.00 / 0.25 \mathrm{~m}^{2}$ and $1.33,3.33$ and7.67and13.33/0.25 $\mathrm{m}^{2}$ during Nov. and Dec. of $2013 / 2014$ and 2014/2015, respectively. After winter months, the values of population density were gradually increased to reach the maximum values during spring months. The highest population densities of adult were detected in mid-April 2013/2014 and 2014/2015 (37.80 and 43.20), respectively. However, the highest population densities of juvenile were detected in the beginning of April 2013/2014 and 2014/2015 (40.40 and 45.80), respectively.

Table 2. Population dynamics of $M$. cartusiana infesting Egyptian clover field at Sheeba village, Zagazig district, during the two growing seasons $2013 / 2014$ and 2014/2015.

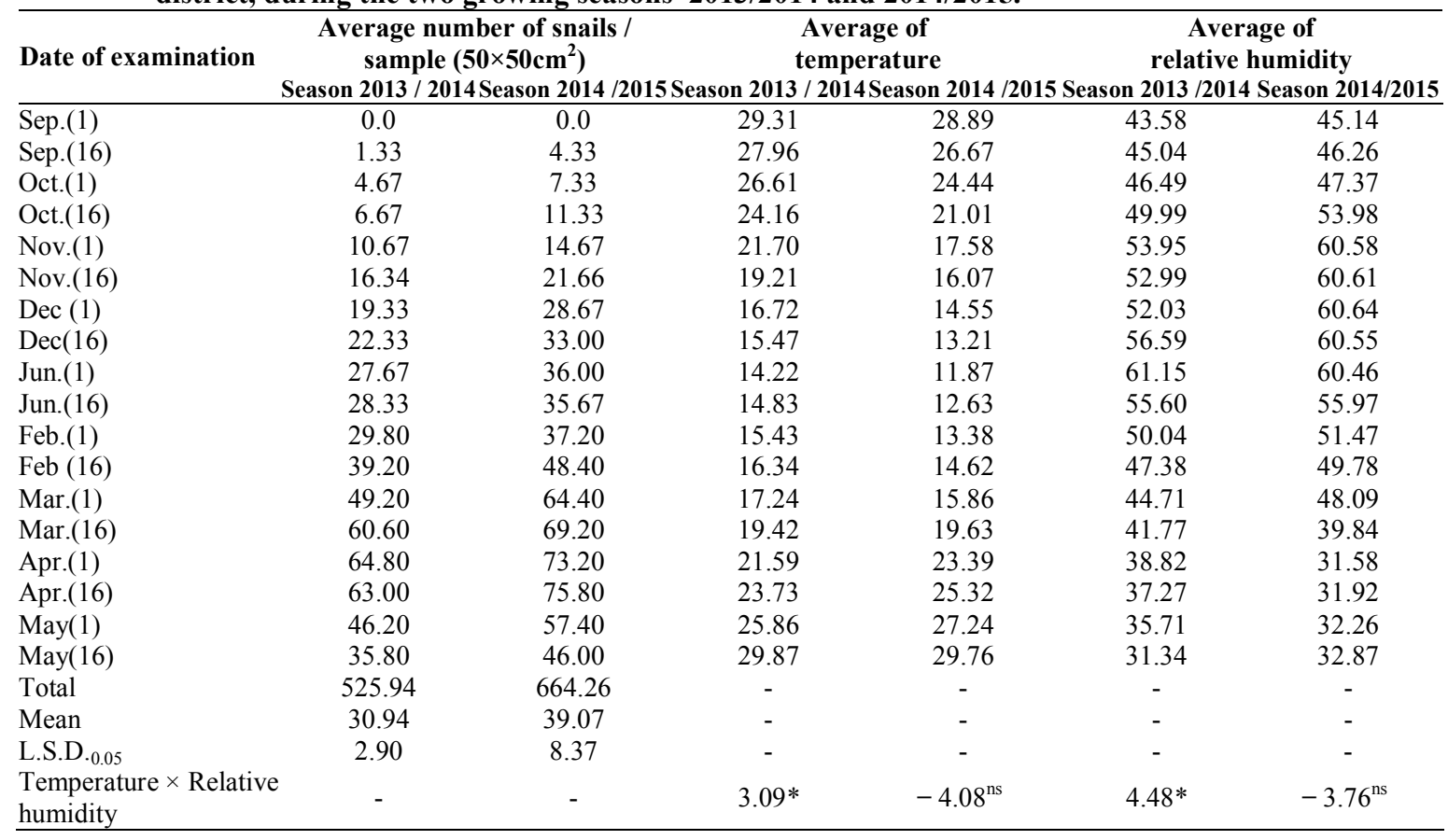

Table 3. Seasonal population fluctuation of juvenile and adult $M$. cartusiana infesting Egyptian clover field at Sheeba village, Zagazig district, during 2013/2014 and 2014/2015.

\begin{tabular}{|c|c|c|c|c|}
\hline \multirow{3}{*}{ Date of examination } & \multicolumn{4}{|c|}{ Average number of snails / sample $\left(50 \times 50 \mathrm{~cm}^{2}\right)$} \\
\hline & \multicolumn{2}{|c|}{ Season 2013 / 2014} & \multicolumn{2}{|c|}{ Season 2014 / 2015} \\
\hline & Juvenile & Adult & Juvenile & Adult \\
\hline Sep.(1) & 0.0 & 0.0 & 0.0 & 0.0 \\
\hline Sep.(16) & 0.0 & 1.33 & 0.0 & 4.33 \\
\hline Oct.(1) & 0.0 & 4.67 & 0.0 & 7.33 \\
\hline Oct.(16) & 0.0 & 6.67 & 0.0 & 11.33 \\
\hline Nov.(1) & 0.0 & 10.67 & 1.33 & 13.33 \\
\hline Nov.(16) & 1.67 & 14.67 & 3.33 & 18.33 \\
\hline $\operatorname{Dec}(1)$ & 2.00 & 17.33 & 7.67 & 21.00 \\
\hline $\operatorname{Dec}(16)$ & 7.00 & 15.33 & 13.33 & 19.67 \\
\hline Jun.(1) & 14.67 & 13.00 & 19.67 & 16.33 \\
\hline Jun.(16) & 17.00 & 11.33 & 21.67 & 14.00 \\
\hline Feb.(1) & 20.40 & 9.40 & 23.80 & 13.40 \\
\hline Feb (16) & 26.20 & 13.00 & 31.20 & 17.20 \\
\hline Mar.(1) & 33.80 & 15.40 & 39.60 & 24.80 \\
\hline Mar.(16) & 36.80 & 23.80 & 42.80 & 26.40 \\
\hline Apr.(1) & 40.40 & 24.40 & 45.80 & 27.40 \\
\hline Apr.(16) & 25.20 & 37.80 & 32.60 & 43.20 \\
\hline May(1) & 14.00 & 32.20 & 25.60 & 31.80 \\
\hline May(16) & 9.20 & 26.60 & 20.20 & 25.80 \\
\hline Total & 248.34 & 277.6 & 328.6 & 335.65 \\
\hline Mean & 19.10 & 16.33 & 23.47 & 19.74 \\
\hline L.S.D. ${ }_{0.05}$ & 1.41 & 1.61 & 4.04 & 6.28 \\
\hline
\end{tabular}

The incidence of land gastropods has been mentioned by many authors in Sharkia Governorate
(Ghamry et al. 1993; El-Masry, 1997; Ismail, 1997; Hegab et al. 1999; Abd El- Aal, 2001 ;Mahrous et al. 
2002; and Lokma 2007). The most of the chosen plants were found heavily infested with $M$. cartusiana, while their infestation with $S$. putris was found light or moderate this finding are quite similar to those previously finding by Gareb,(2007); Shetaia et al. (2009) Ismail et al. (2011); Abou Senna et al. (2016)they reported that the most of examined vegetable and field crops were found heavily infested with M. cartusiana, while S. putris was rarely in its presence in all inspected localities of Sharkia Governorate.

Population density varied greatly in abundance between host plant, seasons and between years, whereas the results proved that Egyptian clover had the highest density of $M$. cartusiana population while broad bean had the lowest . M. cartusiana snails were generally recorded higher density during spring months (in the beginning and mid of April) than winter or autumn months. Population density values on Egyptian clover were much higher in the second growing seasons 2014/2015 than those counted in the first growing seasons2013/2014,indicating the steadily increasing in $M$. cartusiana population. In addition, population dynamics of adults and juveniles $M$. cartusiana fluctuated during the different seasons whereas the activity peak of juvenile snails was in the beginning of April and for adult snails in mid-April during two successive years. These finding are very similar to research results reported by many authors thus, Ismail (1997) who reported that the highest population density of $M$. cartusiana was recorded during spring season followed by winter and autumn, while the infestation disappeared during summer months in certain regions of Sharkia Governorate . Egyptian clover harbored the highest population density of snails, followed by cabbage and wheat. On the other hand, there is no definite correlation between temperature or relative humidity and population density of $M$. cartusiana on the examined crops during the study period. Hegab et al. (1999); Mahrous et al. (2002);Lokma,(2007) Ismail et al. (2011); Awad, (2013)and Abdelkader et al. (2016), they assured that the population density of $M$. cartusiana was obviously increased throughout spring season as compared to low or moderate values during autumn and winter months and no infestation occurred during summer months . Moreover, Egyptian clover harbored the highest population density of snails, followed by wheat. Abou Senna et al. (2016) they found that Egyptian clover harbored the highest population density of snails, followed by wheat and sugar beet during February, March and April and inconstant relationship were found between population dynamics and both temperature and relative humidity.

\section{REFERENCES}

Abd El-Aal, E.M.A. (2001). Studies on certain land snails at Sharkia Governorate. M.Sc. Thesis, Fac. Agric., Zagazig Univ., 124pp.

Abdel-kader, M. R.; Hendy H.H.; Mustafa M.A.; Alakra,T.M.M. and Abdel Al-Maboud M.F.(2016). Ecological studies on the common land snails species in North western cost of Egypt. J. Plant Prot. and Path., Mansoura Univ., 7 (7): 501 505.
Abou Senna, F.M.; Almaraghy, A.H.A. ; Ismail, Sh. A. A. and Abed. M. (2016). Survey, population dynamics of terresterial Gastropod infesting certain crops at Sharkia Governorate, Egypt. Int. J. Adv. Res. 4(11), 641-649.

Acuna, D. de O .F. ;Brandolini, S.V.P.B. 2007). eproductive behavior of Achatina fulica Bowdich, 1822 (mollusca, Achatinidae) in experimental conditions. Instituto de Ciencias Biologicas, Universidade Federal de Juiz de Fora, Brazil, Revista Brasileira de Zoociencias, 9,1,57-61, 8ref.

Arafa A. A. I. (2006). Studies on terrestrial molluscs in some Delta Governorate. Ph.D. Thesis, Fac. Agric., AL-Azhar Univ., 167 pp.

Awad, M.H.M. (2013). Local control and population density studies on land snails in South district of Port Saied, Port saied Governorate. Egypt Acad. J. Biol.Sci.,5(2):47-63.

Baker, G. H. and Vogelzeng, B. K. (1988). Life history population dynamics and polymorphism of Theba pisana (Muller) (Mollusca: Helicidae) in Australia. J. Applied Ecol. 25: 867 - 887.

Barker, G. M. (2002). Mollusks as crop pests. CAB, International, Walling Ford Oxen 108 D.E.U.K., 468.

Costat Statically Computer Program (2005).Co-Hort software, copy right (c) 1998 - 2005, PMB 320, Monterey, CA, 93940.USA.

El-Massry, S. A. A. (1997). Studies on the control of some land snails infesting certain fruit trees. $\mathrm{Ph}$. D. Thesis, Fac. Agric. Zagazig Univ., 150 pp.

Ghamry, E.M. ; EL-Deeb, H.I. and Kokab, Y.A. (1993). Ecological and morphological studies on certain land snails at Egypt. J. Appl. Sci, 8(1):213:225.

Ghareb, Hend SH.(2007). Studies on certain internal and external parasites infesting some land snails. M.Sc. Thesis, Fac. Sci. Banha Univ., 147pp.

Godan, D. (1983): Pest slugs and snails, biology and control. Fedral Biological Res. Centre of Agric and Forest Konigin Luisestrabe 19 D- 400 Berlin 33-345 pp.

Hegab, A. M. I.; Ghamry, E. M.; El-Massry, S. A. A. and Hassan, A. I. (1999). Ecological studies on certain land snails in some localities at Sharkia Governorate. Zagazig. J. Agric. Res. 26 (3B): 787-795.

Heikal, M.H. (2015).Biological aspects and population dynamics of three terrestrial snails infesting fruit trees in Egypt. Int. J. Adv. Res. Biol.Sci. 2(1): $169-180$.

Ismail, S. A. A. (1997). Ecology, biology and control of certain terrestrial snails infesting some vegetable and field crops in Sharkia Governorate. Ph.D. Thesis, Fac. Agric. Zagazig Univ., 130pp.

Ismail, A.A. ; El-Massry, S.A.A.; Khattab, M.M. and Hassan, A.I. (2003). Daily activity and damage caused by Eobania vermiculata Müller (Gastropoda) in citrus orchards. Egyptian Journal of Agricultural Research, 18:1-6. 
Ismail, Sh. A. A.; Shetaia, S. Z. S.; Arafa, A. I. and Abd-El-Atty, S. F. (2011).Incidence and seasonal fluctuation of certain land Gastropod species associated with some crops and weeds at Sharkia Governorate. J. Plant Prot. and Path., Mansoura. Univ., 2 (12): 1103-1110.

Lokma, M. H. E. (2007). Studies on some terrestrial gastropods injurious to field crops at Sharkia Governorate. M.Sc. Thesis, Fac. of Agricultural. Zagazig.Univ., 147pp.

Mahrous, M. E.;Ibrahim Mervat, H. and AbdEl- Aal, E. M. (2002). Occurrence, population density and importance value of land snails infesting different crops in Sharkia Governorate, Egypt. Zagazig J. Agric. Res., 29 (2): 613 - 629.

Sallam, A.A.A.; El-Massry, S.A.A.and Nasr, I.N. (2009). Chemical analysis of mucus from certain land snails under Egyptian conditions. Archives of Phytopathology and Plant Protection 42: 874881.

Shahawy, W.A.; Hendawy, E.; Abada, A.S,A.and Kassem, A.A. (2008).Land snails infesting rice plants and their accompanied parasitoids and predators at Kafr El-Sheikh Governorate, Egypt. Egyptian Journal of Agricultural Research 86: 971-980.
Shetaia, S.Z.S.; Ismail, Sh. A. and Abdel-kader, Samah, M. (2009). Survey, population dynamics and importance value of certain land snail species infesting different crops in Sharkia Governorate. Egypt. Acad. J. biology.Sci. 1 (1): 37-43.

Solem, A. (1984).A world model of land snail diversity and abundance. In : Solem A., Van Bruggan A.C. (Eds.). World-Wide Snails: Biogeographically Studies on Non-Marine Mollusca.Leiden.,6-22.

Speiser, B. and Kistler C. (2002). Field tests with a molluscicide containing iron phosphate. J. Crop Protec., 21: 389-394.

Staikou, A. and Lazaridou- Dimitriadou, M. (1990). Aspects of the life cycle, population dynamics, growth and secondary production of the snail Monacha cartusiana (Muller, 1884) (gastropoda: Pulmonata) in Greece. Malacologia, 31 (2): 353 362.

Staikou, A.; Lazaridou- Dimitriadou, M. and Farmakis, N. (1988). Aspects of the life cycle, population dynamics, growth and secondary production of the edible snail Helix lucorum Linnaeus, 1758 (Gastropoda: Pulmonata) in Greece. J. Moll. Stud. 45: $139-155$

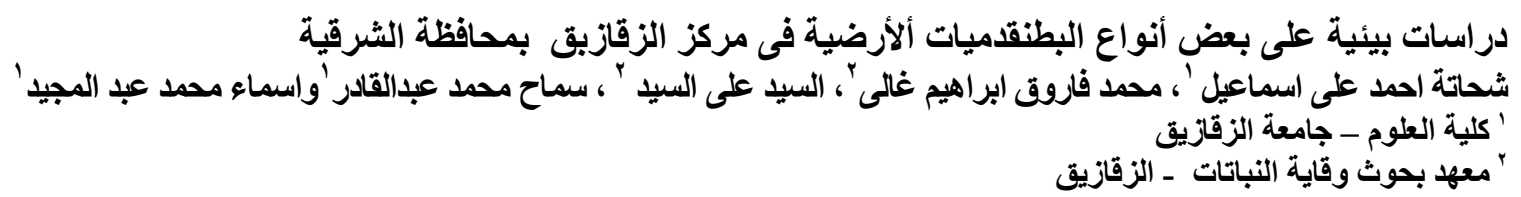

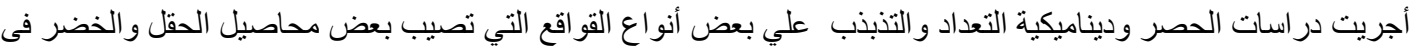

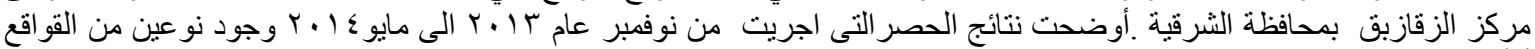

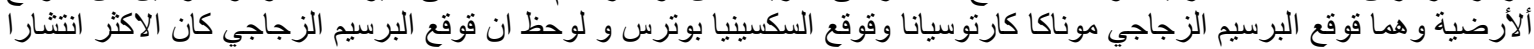

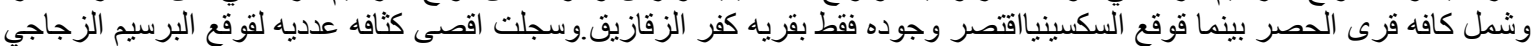

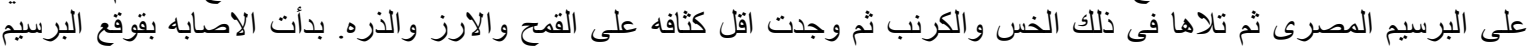

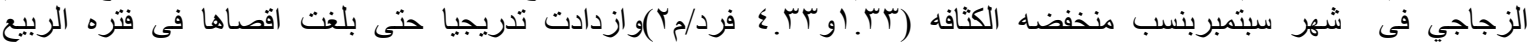

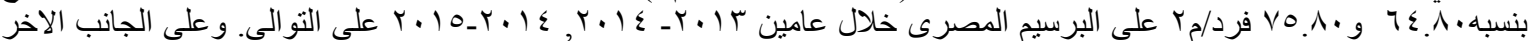

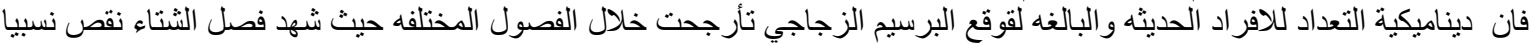

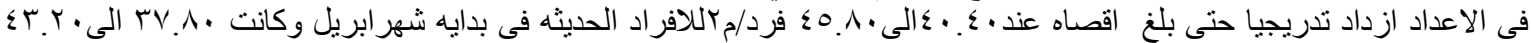

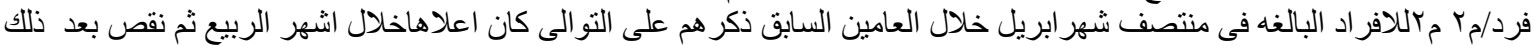

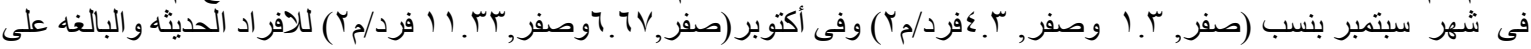

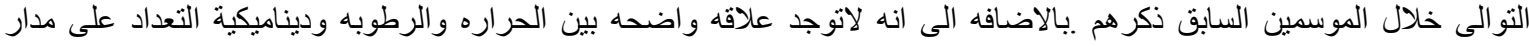
الموسمين. 